Santa Clara University

Scholar Commons

History

College of Arts \& Sciences

2003

\title{
Utopian Androgyny: Romantic Socialists Confront Individualism in July Monarchy France
}

Naomi J. Andrews

Santa Clara University, nandrews@scu.edu

Follow this and additional works at: http://scholarcommons.scu.edu/history

Part of the Feminist, Gender, and Sexuality Studies Commons, and the History Commons

\section{Recommended Citation}

Andrews, Naomi J. (2003). Utopian Androgyny: Romantic Socialists Confront Individualism in July Monarchy France. French Historical Studies 26.3 (2003) 437-457.

This Article is brought to you for free and open access by the College of Arts \& Sciences at Scholar Commons. It has been accepted for inclusion in

History by an authorized administrator of Scholar Commons. For more information, please contact rscroggin@scu.edu. 


\section{Utopian Androgyny: \\ Romantic Socialists Confront Individualism in July Monarchy France}

\section{Naomi J. Andrews}

The two sexes will be but one, according to the word of Christ; the great androgyne will be created; humanity will be woman and man, love and thought, tenderness and force, grace and energy.

Abbé Constant

In a certain respect, nineteenth-century intellectual and political history is the story of the liberal individual and his foes. From conservative Christian thinkers to Socialists to Communists, French intellectuals of the first part of the century were engaged in one long conversation about the individual and his (and later, her) rights, responsibilities, and relationship to society. This conversation was not narrow or singular, as it engaged questions of economic equality, political rights and participation, and gender equity and equality.

Socialists of the pre-Marx generation in particular articulated their critique of capitalism and the politics it spawned through their analysis of individualism. These critiques were both explicit and metaphorical. One theme in particular stands out as both puzzling and recurring in the writings of French thinkers throughout the century: androgyny. 1 During the turbulent decades of the July Monarchy especially, romantic socialists repeatedly employed the trope of androgyny in both their utopian writings and their critiques of the prevailing social order. This article uses the writings of Pierre Leroux; Simon Ganneau, a.k.a. Le Mapah; Abbé Alphonse-Louis Constant; and Louis-Jean Baptiste de Tourreil on androgyny to open a window on the intellectual landscape of romantic socialism. In these works androgyny serves as a metaphorical [End Page 437] prism, an image that reflects the writers' views on the individual, on society, on sexual difference and the roles it imposes, and, last but not least, on the world as it should be.

This essay is an attempt to situate the socialist use of the androgyne in the ongoing conversation about the individual; specifically, the androgyne was in part a metaphorical response to the emerging-though, arguably, not yet hegemonic-masculine individual of liberalism. Feminist scholars of the past generation have undertaken a widespread deconstruction of the individual as the underpinning of liberal-and in the French case, 
republican-political structures. Beginning with critiques of Enlightenment universalism and its blind spots, historians have shown the extent to which the abstract ideal of Universal Man necessarily depended on the unacknowledged presence of a Particular Woman, so to speak. $\underline{2}$ Historians Joan Scott, Genevi ve Fraisse, and Joan Landes have all described, in various ways, the process by which the universal individual that emerged from Enlightenment and revolutionary theories and practices came to define the limits of citizenship and participation, effectively excluding women from the category of "individual" while maintaining the universalist myth of inclusion so treasured by French political culture. $\underline{3}$ This exclusion was effected in a variety of discursive ways: rhetorical representations of the individual that emphasized supposedly masculine qualities like reasoning and objectivity; visual representations depicting the citizen in the form of the bourgeois man; medical discourses emphasizing the hypersexualized and essentially unhuman nature of women. 4 The developing republican political culture defined the citizen by contrast with the unruly, partial, and sexualized female. Romantic socialism generally and its use of the androgyne specifically are in part a response to the cultural assumptions of Enlightenment and republican political culture, as well as to the more general economic and political environment of the early nineteenth century. $\frac{5}{\text { [End Page }}$ 438]

The image of the androgyne, with its indeterminate bodily boundaries and internally divided nature, stands as an embodied alternative to the atomized individual. In The Body and the French Revolution, Dorinda Outram describes the way that the contained, bourgeois, masculine individual emerged during the French Revolution as the symbolic rights-bearer, and how what she calls homo clausus, following Norbert Elias, came to symbolize in visual terms the exclusion of both female and lower-class people from the body politic. The figure of the androgyne is a prime example of how the imagery of the body worked to shape political conceptions about entitlement. $\underline{6}$

The works of philosopher Denise Riley and social historian Jacques Donzelot have helped to define the social as a newly emergent object of human inquiry in the nineteenth century. $\underline{Z}$ Defined and gendered in specific ways, the social came to be the repository of the poor, the feminine, and the victimized. In simultaneously embodying and advocating for this realm, women developed a shadow network of social influence and power, one which eventually was used to argue for their inclusion in the political realm. $\underline{8}$ Drawing on the works of Riley and Donzelot, Claudia Moscovici argues that the nineteenth century saw the redefinition of the liberal individual through what she calls a "double dialectical process" that produced, alongside political man, social woman. Moscovici shows how the androgynous "ambi-sexual" individual emerged to contest, though never fully successfully in the nineteenth century, the primacy of the liberal individual and in a thoroughgoing way to question the gender of citizenship. $\underline{9}$

In this article I draw on these theoretical and historical accounts of the gendering of the individual to explore the symbolic work done by the androgyne in French romantic socialist texts of the $1830 \mathrm{~s}$ and $1840 \mathrm{~s}$. The androgyne operates in these texts in a multitude of ways: as a symbol of diversity in unity, as a site where the social individual -one inclusive of both women and men-is being articulated, as a symbolic rebuke of the universalist individual of liberalism, as a utopian [End Page 439] embodiment of reconciliation between the sexes, and as an imaginative meditation on the nature of the individual in the social world. 
Mythological as well as contemporary depictions of androgyny most frequently present a single human figure with either sexual characteristics of both sexes or indeterminate sexual identity. $\frac{10}{}$ However, the depictions of androgyny offered by socialists of the July Monarchy typically used the term to refer to something that looked more like an idealized marriage, combining in harmony the feminine and the masculine. $\frac{11}{\text { Classical }}$ representations of the androgyne, and even other nineteenth-century literary representations-such as Fragoletta by Henri de Latouche, Séraphita by Honoré de Balzac, and Mademoiselle de Maupin by Théophile Gautier-presented one creature that physically combined masculine and feminine sexual characteristics. In contrast, the androgyne in romantic socialist texts was spiritually or psychologically one, but maintained discrete feminine and masculine bodies within its newly joined whole. In fact, though they exclusively used the term androgyne to refer to this being, the term hermaphrodite as it was used in Plato's Symposium better reflects the picture being drawn. In bringing together the opposite elements masculine and feminine, the romantic socialist androgyne created unity in diversity, through which the divisiveness of modern society seems to be overcome and the social nature of mankind underlined.

The conception of gender as idealized and based in physical difference that underlies the romantic socialist image of the androgyne is emblematic of the period. As scholars have extensively discussed, the idealized feminine was an important political and philosophical construct of the romantic period. 12 This is no less true of romantic socialism, which used idealized images of femininity to represent utopia and drew on traditional imagery of the Virgin Mary in defining women more generally. Likewise, as historian Robert Nye and others have recently shown, notions of masculinity were equally rigid, though not necessarily [End Page 440] as disempowering as those of femininity. In either case, prescribed behaviors, realms of interest, action, and sentiment were culturally defined for men and women. $\underline{13}$

The union of opposites embodied by the androgyne was suitable not just to represent the union of man and woman, but equally to represent the union of the various opposing forces in the world in which these thinkers lived. As Victoria Thompson notes, "ambiguous gender and sexual identity functioned as a metaphor for a society in which social and economic boundaries were perceived as permeable." $\underline{14}$ Whether bridging class barriers, the distance between producer and consumer, or even the gulf between the West and the East, romantic socialists sought the reworking of society on grounds of love and cooperation.

Though all were loosely connected with the milieu of romantic socialism, the four thinkers discussed here were by no means unified in their vision of the good society. Indeed, by comparing their writings, one of the central fault lines of socialism is well illustrated: the balance struck between the needs and rights of the individual person versus those of the society as a whole. $\underline{15}$ In their depictions of the androgyne these thinkers make evident their priorities. For Leroux and Ganneau, the sanctity of the person had always to be balanced against the claims of the community, while for Constant and Tourreil the problem of balancing seemed most easily resolved by effacing individual identity. That the vehicle by which these thinkers worked out the tension between the individual and society was the androgyne demonstrates anew the interdependence between ideas of sexual difference and individualism in nineteenth- 
century French intellectual life.

\section{Pierre Leroux:}

\section{Nostalgic Androgyny and the Origins of Humanity}

I begin this discussion with Pierre Leroux (1797-1871), one of the best known of the generation of romantic socialists active before and during 1848. He had a long and prolific publishing career, acting as both printer and publisher of the important journals Le globe and L'encyclopédie nouvelle. After his brief involvement with the SaintSimonian movement, [End Page 441] he became an independent socialist thinkernever inspiring a formal école, but broadly influential nonetheless. Leroux had close ties to the women activists of the Saint-Simonian movement, such as Jeanne Deroin and Pauline Roland, and, perhaps most notably, he was George Sand's close friend, spiritual mentor, and, often, dependent. Leroux gave currency to the term socialisme itself, and was one of the thinkers who helped give coherence to the romantic socialist movement more generally. Leroux's treatment of androgyny is my starting point because of his centrality to the socialist movement during the July Monarchy. $\underline{16}$

In De l'humanité, one of his two major philosophical treatises, first published in 1840, Pierre Leroux narrated and interpreted the biblical creation myth, articulating through the symbol of the androgyne his views on the individualism of his day. The androgyne presented in his work is a nostalgic androgyne posited as the origin of a now-troubled mankind. Drawing on the works of several mystical thinkers of the previous generation, Leroux defines the first man as an androgynous reflection of the nature of God. $\frac{17}{\text { As }}$ Leroux himself carefully demonstrates, this view of Adam and Eve is not a novel one. What is new, however, is Leroux's socialist perspective on his discussion, which presents androgyny as a foil for atomized individual identity. By using it in this way, Leroux writes androgyny as a communitarian symbol of human interconnection. In Leroux's depiction of androgyny, Adam and Eve remain always that-Adam and Eve, two distinct beings. Leroux's discussion of the androgyne is thus his means of concretizing the inherent tension (much discussed elsewhere in his writing) between the individual and the community. In this he differed substantially from the other writers discussed here. Where they sought symbolically powerful but not necessarily philosophically or psychologically complex solutions to the problem of the atomized modern world, Leroux was himself troubled both by the fragmentation of modernity and by the authoritarian, leveling inclinations of his fellow socialists. $\underline{18}$

Leroux's creation myth is predicated upon the idea that biblical Adam is not an individual person but a symbol for all humanity: "Evidently, the man who comes at the end of all these creations is the potential being man, considered as a unity, a generic life, collective, immortal, capable of concentrating himself or expanding himself, unlimited, [End Page 442] as a consequence, in time and space." This humanity is generalized and undifferentiated, and in each man all of humanity is recapitulated: "Humanity is in each man, and each man is humanity." $\underline{19}$ Humanity is thus multiple and singular simultaneously. Leroux defines androgyny in the same terms: androgyny is a crystallization of unity-in-duality, symbolizing difference and wholeness at the same moment.

After universalizing Adam to represent all of humanity, Leroux describes Eve's creation. Eve was not made from a part of Adam; rather, the scene in which God extracts a rib 
from Adam's side stands for the separation of an already dualistic, and previously gendered, androgynous creature. In this Leroux follows the original Greek scriptures, without assigning blame to Eve, as did Latin and later English translations, and implicitly thereby denies original sin and women's lot as its result. $\underline{20}$ Gender predates individuality in this scenario. Before there was man and woman there was masculine and feminine: "This humanity, that is to say this man-humanity, emanates first of all from the divine thought, masculine and feminine at the same time, reuniting in its unity the two principles." $\underline{21}$ There was no separate creation of Eve from Adam, but a physical division of an already two-part creature, as in the hermaphrodite described by Aristophanes in Symposium.

There were two bodies completely formed and developed, that is to say that the primitive human body was double, male and female, and that the creation of Eve was only the division of two bodies. ... the text of the Bible expressed that God separated from the body of Adam the organ of the feminine sex, or rather the feminine principle, and made from it woman. . . Eve preexisted in Adam, and there was not there a true creation, but only a separation of the two principles of the androgyne. $\underline{22}$

Although Adam is the container in which Eve is subsumed, her essence, her feminine nature, existed in a prior way within him. And yet the creation of man and woman as distinct people is not completed by this separation. They remain joined in the androgyne, unaware of their individuality as of yet.

Humanity is created in a tripartite process: first the androgyne was created, then separated physically into man and woman, and finally, as a result of the fall from grace, it was psychologically separated. The sense of connection between the two separated parts of the androgyne [End Page 443] outlasts their physical separation, again following Plato. In Leroux's account, Eve is both Adam's "self and non-self, by an inconceivable mystery," and although they are clearly on the path to a future and fully separated existence, the distinction is, as of yet, incomplete; "identity and distinction were revealed to them at the same time." $\underline{23}$ This moment, when Adam and Eve both exist as distinct physical beings and yet are not fully individuated, is the zenith of Leroux's Eden. It is also the moment to which he would return in seeking both human happiness and woman's greater equality. Each is incapable of seeing the other as entirely separate from him- or herself, and thus they cannot yet develop interests in opposition to each other. They are still primarily aware of themselves as part of "the Universal Life," as Leroux refers to the collective consciousness of humanity.

The real tragedy in the Fall is not the expulsion from Eden-that is only a result-but rather the knowledge that the fruit imparts to Adam and Eve. The knowledge humanity acquires with the Fall is that of individual identity, the sin of ego. It is the sense of interconnection and common identity, which Adam and Eve maintained after their separate creation, which is lost when the fruit is eaten. When Adam and Eve gain knowledge of their own individuality the troubles begin: "Man began by separating himself, individualizing himself in an absolute fashion; and there was evil." $\underline{24}$ Human beings can only know their own mortality when they begin to conceive of themselves as isolated, separated atoms, whose death signifies an absolute end of existence. Humanity as a collective consciousness is immortal, reproducing and perpetuating itself eternally. Lacking the knowledge of a separate self, immortality and innocence are forever preserved. Androgyny is the state of interconnection and egoless bliss. 
Although he used the term androgyne, what Leroux at first glance seems to be describing is really some kind of divine marriage, complementarity in its ideal form. In many ways, it mirrors the Christian notion of marriage that calls for the spiritual and physical union of man and woman. Where androgyny differs from marriage is in the physicality of its connotation, as it is a material union of man and woman. It conjures an image of a physically unified creature in a way that no use of the term marriage ever could, despite Leroux's description of a physically but not psychologically separated being. This kind of physicality echoes the physically distinct body of the atomized individual that Leroux describes elsewhere as "isolated in space, without family, without [End Page 444] country, without property; declared, in a word, free of all solidarity." $\underline{25}$ Whereas the clear boundaries around the liberal individual are key to its identity, the indeterminate boundaries of the androgyne are pivotal to its construction and to its resonance as a symbolic response to individualism. Without precision about their existence and whereabouts, we cannot define the beginning and end of the individual. If I do not know where I end and you begin, I cannot objectify you or define oppositional interests between us. Thus the figure of the androgyne is a powerful conceptual antidote to the atomized human beings created by competitive social relations. Leroux used the androgyne strategically to refute the abstracted individual of contemporary economic and political thought, offering in it a double-edged reproach to that individual, one that corrects for the definitional shortfalls of the masculine individual by writing both femininity and community into the definition of humanity.

As a symbolic refutation of the individual, however, Leroux's androgyne is puzzling, even unsatisfying; in this it accurately reflects the ambivalence of Leroux's own position on early socialism's threats and promises. On the one hand, we are told that it was at origin male and female both, that Eve's creation was in fact only the separation of two already distinct essences. Yet Leroux seems also to argue for the eradication of sexual difference through the physical union of man and woman. Leroux's ambivalence reflects, I think, several key aspects of his thought and of the discursive context in which he wrote. First of all, it drives home how much gender and its definition have to do with thinking about individualism; though in many ways the androgyne is about the dissolution of individual identity, some differences are, apparently, indissoluble. And although a unified body of some sort or another (the image never becomes physically clear in Leroux's depiction) is the seeming symbolic point of the discussion, Leroux's insistence on the integrity of the individual despite his profound embeddedness in other networks of identity-community, family, patrie-is well served by the symbol of the androgyne. As it stands in his representation, the androgyne is the perfect representation of unity in diversity, containing the indissoluble masculine and feminine essences. That is to say, without the notion of radical sexual difference that underlies Leroux's understanding of social relations, the androgyne would not be such an alluring symbol of unity. [End Page 445]

\section{Ganneau:}

\section{Association, Salvation, and Androgyny}

If Pierre Leroux's depiction of the origins of humanity presented androgyny as the state of innocence, then the androgyne presented by Simon Ganneau (180?-1851) ought to be seen as the salvation of mankind. Ganneau, who called himself both "he who was Ganneau" and also Le Mapah, $\underline{26}$ was an eccentric former phrenologist who had 
significant influence on his contemporaries but very little popular impact. His garret apartment on the lle Saint-Louis was visited by many of the more mainstream and prominent socialist and republican thinkers of the day, including Alexandre Dumas, Félix Pyat, Alphonse Esquiros, and the Fourierist leader Victor Considérant. $\underline{27}$ Ganneau was a sculptor who "spread his doctrine in the form of 'plasters,' plaster figurines of strange appearance, without doubt symbolically bisexual." $\underline{28}$ None of the sculptures have survived but several of his idiosyncratic pamphlets, also called "plasters," have, all of them signed from the grabat, or pallet, of Le Mapah. Ganneau and Leroux both appeared as contributors to an ephemeral paper from 1848 titled La montagne de la fraternité, along with other socialist luminaries of the period such as Georges [sic] Sand, Pierre-Joseph Proudhon, and Félicité Lammenais. $\underline{29}$ Ganneau died in 1851 and was survived by his sole disciple, Charles Caillaux, or "he who was Caillaux." $\underline{30}$

Pierre Leroux was a philosopher-politician of a recognizable type; he generally limited the more fantastical aspects of his thought to heavy philosophical treatises. Ganneau, on the other hand, went beyond philosophical speculation about the nature of humanity. He proclaimed himself the androgyne, a messiah-or as literary historian Paul Bénichou calls him, a pope-for the age of association. $\underline{31}$ In several short pamphlets written between 1838 and 1840, Ganneau presented androgyny as the embodiment of the key socialist concepts of association and unity [End Page 446] and linked it conceptually to the other embodied figure beloved of early socialists, la femme.

In the earliest of his pamphlets, titled Bapt me, mariage and dated 15 August 1838, Ganneau announced his allegiance to Mary the mother of God as the true savior of humanity. Ganneau drew an analogy between Mary and Eve and between Christ and Adam and then went on to "marry" the two figures into the androgyne Evadam, a new social unity-reminiscent of the Saint-Simonian couple and God $\underline{32}$ —of which Mapah proclaimed the gospel. In proclaiming this new Word, he coined a few of his own:

In the Name of the Great EVADAH, [the Mapah] constitutes you and proclaims you to the world, the great symbol, and the great personification of unity in duality. And you, Mary, you Mary-Eve of Genesis, female unity, you, ChristAdam of Genesis, male unity, under the name ANDROGYNE EVADAM! By the great marriage, we, Mapah, want, men, that your mothers, your sisters, and your fiancées, great pariahs, until then unnamed, bring to marriage the first term of their name, and you fiancés, the first term of yours, in order that these two genders be constituted unity in duality, thus EVADAM, from Eve and Adam. $\underline{33}$

Androgyny here, as in Leroux's depiction of it, represents divine marriage, one in which the wrongs of traditional marital relations can be corrected: "Roman Catholic marriage is only the symbol of the consecration of the absorption of the female element by the male element. We consecrate, however, the precedence of the woman in the name of the Androgyne and consecrated by the new marriage, because she gives birth in pain."

Androgynous marriage of the sort Ganneau proposed is a way of balancing the feminine and masculine elements within the union, and by extension, within the wider world, because this Mary-Christ union is to be the means of humanity's salvation. Ganneau did not explore the incestuous implications of this union; in fact, it appears that he was using Mary and Christ as idealized types of man and woman, without recognizing their 
familial relationship. Nevertheless, the implications of this incestuous androgyny are intriguing: If Mary and Christ are reunited into one being, is he not returning to the womb, and in a certain sense is not man being (re)absorbed by woman? As Ganneau said, [End Page 447] Christian marriage entails the absorption of woman by man. Through his incestuous uniting of Mary and Christ, Ganneau turned that absorption around, with Christ being subsumed within Mary.

Ganneau's androgyne is a symbol of both duality and unity; in it, sexual difference is maintained despite the unification of the two beings. Ganneau called this "Evadian Unity." It preserves difference yet emphasizes and glorifies interconnection and the identification of the part with the whole: "Evadah is great. It is one in matter and spirit, it is the unity duality." $\underline{34}$

Evadian Unity is also found in another familiar concept, association, which Ganneau discussed in Waterloo, dated 14 July 1840 . He used the term as it was popularly understood at the time to mean a form of economic and social union among workers. It is also worth noting that like androgyny, association was an early socialist response to individualistic economic practices. Ganneau made the connection between unity and association in a parable of separated grains of sand crying to God about their vulnerability to the elements. God tells them to associate, and among the results are the Pyrenees and the Alps, which Ganneau called the scaffolding/skeleton of the world: "The partitioning [morcellement] is Division, Misery, Night. Association is Unity, Goodness, Light." As was the case for Leroux, so for Ganneau the good always lay with unity, and evil, with division:

Humanity at this hour is dissolved down to its last element, the individual, and the atom. All at this hour, we are murdered atoms who cry to God: Mercy! God responds to us: ASSOCIATION! Sisters and brothers in sadness, let us associate, and we will be giants, the new scaffolding of humanity transfigured, that is to say, associated, unified! The law of Association calls itself in the atomic world Attraction, in the intellectual world, Love. I tell you in truth: the matrix of Attraction, of Love, and of its beautiful fruit, Expansion, is Evadian Unity. Evadian Unity is the Epic of human life in all its modes of manifestation. ... In Evadian Unity all are called, all are elected, all are rehabilitated. $\underline{35}$

Androgyny and association appear here as alternative ways to symbolize a harmonized society. Androgyny is posited as alternative "scaffolding" for humanity, a potential route toward unity and harmony in society, much as association is presented as an alternative form of social organization; both embody unity, and both challenge the primacy of the liberal individual as the basis of social organization. [End Page 448]

Ganneau, as was the case with others in his circle, worked with an idealized and exalted image of woman. $\underline{36}$ His elevated prose when discussing the beauty and suffering of Mary attest to this idolization. These images of woman are representative of what some historians call the early feminist consciousness of the romantic socialist movement, which categorized many of the qualities they wanted for their ideal society as feminine attributes. $\frac{37}{2}$ Love, charity, unity, self-sacrifice, and other such qualities fell under the "feminine" rubric in their writing.

Throughout his writings, Ganneau inflected traditionally masculine entities with these feminine attributes. When he renamed God Evadah, thereby emphasizing the female and 
male attributes of the deity, he forever changes the impact of the trinity: "The traditional Trinity, entirely masculine, could not survive in a two-sexed God." In Bapt me, mariage Ganneau identified Mary, not Christ, as the savior. When he connected the two in the divine androgyne, he redefined marriage, rejecting the traditional marital arrangement of Roman Catholicism and the French code civile. This "irruption of the feminine principle confuses the distribution of the divine persons" and redefines and feminizes the formerly masculine realm of God, Christ, and the Trinity. $\underline{38}$ The androgyne is therefore a union of Mary and Christ that empowers feminine qualities with the salvation of humanity. This androgynous union has the effect also of raising Mary to the level of Christ, his equal as savior and as a man. Inasmuch as the religious hierarchy reflects the traditional hierarchy of human society, Ganneau symbolically equalizes women's position in the world when he does so for the heavenly configuration.

Androgyny and association are the fundaments of Ganneau's utopian alternative. They are conceptually linked in his writings by two key characteristics: the blurring of distinctions between individuals, and the erasure of selfish egoism. The salvation of mankind will come in the form of an androgynous marriage of Mary and Christ. The world to which humanity will be led is characterized by unity and love, the primary qualities of woman in his worldview. These qualities are posited in opposition to the atomized, divided, and implicitly masculine individual who could never make a mountain on his own. Ganneau's androgyne is thus a unified human body to stand as an alternative to the isolated and vulnerable individual that is the cornerstone of the social and economic system Ganneau is rejecting. [End Page 449]

\section{The Abbé Constant: Revisiting the Holy Trinity}

Abbé Alphonse-Louis Constant (1810-75) also gave androgyny a key role in his utopian vision. Constant was a priest manqué who had a long-standing battle with the Catholic Church over his interest in both feminist and workers' causes. Many of his writings were produced during his tenure with the church, and this is reflected in his preoccupation with the trinity and more particularly with the Virgin Mary. $\underline{39}$ The androgyne appears at apocalyptic moments in his writings, marking turning points in the progress of humanity. Like Ganneau, Constant used Mary and Christ as archetypal figures of man and woman, depicting them as united into a divine androgyne heralding humanity's rebirth. Also like Ganneau, and arguably Leroux, Constant identified the androgyne in feminine terms, linking it conceptually and strategically with the achievement of a feminized utopian society, ruled both by women and by feminine values.

As with Leroux's idealized origin of humanity, social harmony is symbolized by the androgyne in Constant's writing as well. In a poetic commentary on the Song of Songs he painted the following tableau:

The Christian symbols represent to us Charity with the figure of a woman who gathers around and presses many children to her milk-filled breasts. Such will be our new society. The two sexes will be but one, according to the word of Christ; the great androgyne will be created; humanity will be woman and man, love and thought, tenderness and force, grace and energy. Society will be a mother who will share bread with all according to their needs and to their efforts; she will carry in her arms those who cannot yet walk; she will nourish 
with her milk, with the sweetest food, those who are in need; and the children will join hands around her; the biggest will help the smallest and remove from their path the rock that would make them fall. $\underline{40}$

In this passage, echoes of Ganneau's association and of Leroux's prelapsarian androgyny are evident: competitive social and economic practices are no more, and sexual difference no longer serves as a marker for discord.

Constant was very clear about the economic conditions in which this new world can be achieved: the rich and the poor will both disappear in the future, and the fruits of the earth will be equally bestowed upon all. He described an economically leveled, identifiably "socialist" [End Page 450] society, one that distributes its riches on the basis of need, not of achievement. Maternal images recur here: after the end of the division of humanity into rich and poor, "the earth then will no longer be a cruel stepmother, and men will bless God; and they will love each other." $\underline{41}$ When competition has ceased to rule the day, the earth will amply provide for all. Starkly evident both here and in many of his other writings is the absence of a powerful masculine figure. Where man is defined, it is usually in very personal terms: Constant himself is the man, where woman is an abstraction or series of idealized figures. Indeed, more generally in these texts, masculinity remains largely outside the discussion, while definition and reinterpretation of femininity is an almost obsessive practice.

The harbinger of Constant's utopia is the divine androgyne, which Constant described as the "second marriage of man with woman," and as the "fondest dream of men of the future." The androgyne will appear when "Adam will have pardoned his companion. .. . Perfect Love will then have been achieved and sin effaced." $\underline{42}$ The androgyne represents the final reconciliation of competing forces, whether male/female understood literally, or more generally to stand for social and economic forces.

The forgiveness of sin and the eradication of lust from male-female relations are recurring motifs in both Constant's and other romantic socialist writings. Romantic socialists frequently played with themes of female sexuality, attempting in both real (as in the case of the Saint-Simonian movement) and in rhetorical ways to destigmatize women from the stain of original sin. Constant did this by unsexing the androgyne, the product of a chaste union, one that embodies love through the denial of sexuality. Echoing ascetic Christian sentiment, and his own background as an aspiring priest, Constant opined, "Chastity is true love." $\underline{43}$ Constant's androgyne, as part of this discussion on female sexuality, can be read as a feminist symbol, standing for the amelioration of the two most permanent sources of woman's inequality in society: her condemnation for Eve's original sin, and her status as sexual object for men.

Echoing Ganneau's definition of association, Constant related the androgyne to the socialist ideal of humanity: "And we, as weak individuals, divided from humanity, we no longer exist." $\underline{44}$ Through the chaste [End Page 451] union of man and woman the divine androgyne is created, representing the union of humanity and the "smile" of God. The result is blissful: "God alone lived in us; he thought in me, he loved in her; he was happy in both of us. We were a form of his eternal marriage, a word of his contract with humanity, a smile of his happiness, a tear of his joy, a sigh of his ecstasy." God lived in them, but acted differently through each, as they still existed as separate beings. This point stands in interesting contrast with Constant's own proclamations about the idealized union of mankind: he himself calls for a world in which all differences, 
especially those of sex, will disappear. Furthermore, in his description of the entity called humanity, all boundaries, of whatever sort, are erased: "The whole of this people then grouped itself and reunited itself in a single human form." $\underline{45}$ When considering humanity as a mass, Constant could envision overcoming all difference, even sexual difference, but when the focus of his thought is a single androgyne, a single couple of man and woman, sexual difference remained the salient characteristic of the being.

The androgyne appears in another guise in La $m$ re de Dieu, Constant's utopian novel, this time as a child symbolizing love and unity: "From our two souls was born eternally a new soul, a celestial androgyne, a child that was at once my image and myself, and the image of my beloved and my beloved herself. We understood then that which was touching and mysterious in childhood; we understood love like the new being produced by the sacred fusion of two beings." $\underline{46}$ This androgyne is a psychological union that effaces the differences between two formerly separated people. Nevertheless, although a physically unique creature, this androgyne is still a composite of two entities, and sexual difference remains central to it. In it can be read the father and the mother, distinct and eternal.

Unity is the defining characteristic of Constant's future society, and it is also a common meaning ascribed to the feminine and the androgynous in his work and that of other romantic socialists. Unity is constantly posited in opposition to the egoism and fragmentation that was the central flaw of the society they denounced. As Constant opined, "Individuals will disappear before the holy unity." $\underline{47}$ Their world was a society of individuals separated from one another; the grains of sand that Ganneau describes that would be able to survive only through association. In taking up the androgyne as one of their symbols of unity, romantic [End Page 452] socialists both highlighted the permanence and metaphorical significance of sexual difference in their worldview and also showed the extent to which they sought a unity that would bridge rather than erase difference.

\section{Louis-Jean Baptiste de Tourreil's Fusionist Utopia}

A great deal of scholarship has been devoted to the socialism of Pierre Leroux, and several scholars have documented the lives and eccentricities of Ganneau and the Abbé Constant. By contrast, a relatively undocumented "messiah" of this era is Louis-Jean Baptiste de Tourreil (180?-1864). $\underline{48}$ Tourreil developed a new religion, called fusionism, which rested on androgynous definitions of both God and mankind. His doctrine predicted the ultimate fusion of all human beings into a singular androgynous one, without separate identity or consciousness. It denied original sin and was consistent with other philosophies of the day in its championing of the "feminine" qualities of unity and love, while decrying the state of women in contemporary society.

According to Alexandre Erdan, Tourreil was a sailor who received a revelation while walking in the Bois de Vincennes sometime during the Bourbon Restoration. Erdan interviewed him for his book La France mystique in the summer of 1854, noting that, "of all the messiahs of these times, M. de Toureil [sic] is the one that, with Ganneau, comes closest to the ideal type." $\underline{49}$ While clearly skeptical about the authenticity of Tourreil's revelation, Erdan did seem attracted by him. "His face, with an intelligent expression, and a rare placidity, is not without some analogy with the ideal depictions of Christ," he wrote. Erdan presents a sketch of the doctrine of fusion, emphasizing unity and erasure 
of individuality-he also referred to followers but provided no documentation, although Maitron tells us that Tourreil had almost no influence during his lifetime. $\underline{50}$ [End Page 453]

Fusionism is a derivative utopia, and while Tourreil did not directly cite his sources of inspiration, it is clear that Leroux and Ganneau were both important. Tourreil borrowed much of his vocabulary from Ganneau directly, and his general perspective on humanity and unity were strongly reminiscent of Leroux's doctrines. $\underline{51}$ Maitron characterizes his religion as a synthesis of the ideas of Charles Fourier and Pierre Leroux, noting that he had indirect connections to the Saint-Simonian movement. $\underline{52}$

Tourreil was a planner, much like Fourier in his preoccupation with numbers and placing people in society based on their inherent qualities. In Tourreil's scheme for the poly me (the name given to his utopian community), the determining factor was not personality type, as in the Fourierist phalanstery, but rather age: a person's stage of development is the central index of his or her place in society. Tourreil's utopian future posits a humanity that is fully fused, and in which individual identity has ceased to exist. Ultimately mankind will live, act, and think as one, being part of a "universal being,.. . itself an androgyne," of a single mind and body. $\underline{53}$

In fusionism, the basic unit of humanity is the couple collectif, or Evadam, echoing the Saint-Simonian idea of the couple as the basis of humanity. In Tourreil's scheme, the universal androgyne is the foundation of society and the reflection of God's perfect androgyny. In the form of Evadam humanity will make the journey toward perfection and thus achieve heaven.

One of the arguments of this article is that the figure of the androgyne presented socialists with a way to depict a unified yet diverse and varied humanity, one that could symbolize both the overcoming of competition in social relations and, arguably, the reconciliation of the conflict between the sexes, while at the same time challenging the emerging idea of the individual as the basis of liberal society. That the androgyne is one yet includes in it the two elements of humanity-masculinity and femininity-makes it an ideal symbol of their more varied society. Sexual difference acts here as a placeholder for all sorts of division in society. When Tourreil discusses the necessity for the sexes, this symbolic function is at work:

Interviewer: Was it necessary that there be two sexes in life?

Interviewee: That was necessary, not only so that the universal being [End

Page 454] manifest infinite multiplicity and diversity of modalities which make the harmony and the beauty of the universe, but this was also necessary in God, so that he could enjoy movement and the ability to create. $\underline{54}$

The two sexes were necessary not because of reproductive needs but for doing symbolic work. It is their very difference that makes the existence of two sexes necessary. God, Tourreil claimed, would have no consciousness, no mobility and no character without the two sexes: He/she/it would be neither active nor passive, unable to be self-reflexive and self-aware without the two sexes, thus occupying all space as an inert and faceless mass. "Therefore, in the absence of two sexes, God would only have been a unity without movement, powerless, solitary, and impossible." $\underline{55}$ In this case as in the other versions of androgyny discussed above, gender is an abstract essence, independent of 
body. As the symbol of difference of whatever sort, it is an eternal quality, divorced from sexed, sexual, or reproducing bodies. Furthermore, the differences it marks are those, when united, that make the diversity of humanity.

Interestingly, despite Tourreil's tendency to divorce sexes from bodies, marriage is the first manifestation of the future androgynous state of mankind according to fusionism. As such its renewal is vital to the utopian project at hand. Throughout the fusionist texts, as with those of the other writers discussed above, marriage and androgyny are only vaguely distinguished from one another. They are, ultimately, part of the same process of human perfection, occurring at different stages in humanity's development. Androgyny denotes here an idealized form of marriage, one that rests on union, connection, interdependence, and love. For Tourreil, "marriage being the origin of society, if marriage were perfect, society would evidently be perfect." $\underline{56}$ Though Tourreil was most expressive in his discussion of contemporary marriage and its discontents, the early feminist agenda of many romantic socialists was arguably derived from similar sentiment.

Tourreil also used androgyny to define the future harmonized state of being, when God will have been achieved. Echoing the more poetically presented vision of the Abbé Constant, Tourreil here used androgyny to refer not to the union of a man and a woman into a new creature, but to the melding of all of humanity into one all-encompassing creature: "It is in blending man and identifying him through fusion [End Page 455] of himself with all other things and all other things with himself, in such a way that each individual be one day identified with all the universe and become the universe itself, through the consciousness which he will have of filling it entirely with his Self." $\underline{57}$

If he was vague about the physical form of universalized humanity, Tourreil was more explicit on the question of what he was rejecting in contemporary society, namely, the individu égo ste. Tourreil offered as proof of his theory of fusion the fact that human beings live and feel themselves in each other. How do we know that this condition is true? All the myriad ways in which we exhibit empathy with one another, by feeling sympathy with the suffering of another, by risking our lives for each other. To the extent that these feelings are not in evidence, it is a result of the retarded development of the individual, not a refutation of the theory itself. This underdeveloped humankind, the selfish individual-also designated as a "passive soul"-is thus defined: "An egoistic soul, that loves nothing but itself, that is repulsive to progress, whose thoughts and sentiments immobilize it in the current moment and make it live uniquely in a life of concentration, does not feel and cannot feel himself beyond his own center of consciousness, for the reason that the exhalations of its soul, in escaping from its body with the bodily emanations, remain in a state relatively concrete and unconscious." The antithesis of this concrete and passive soul, trapped in its own body and unable to feel itself or generalize its experience beyond its own immediate self, is the active soul, which "living the life of expansion and endowed with a well developed physical and moral sensibility, feels itself alive in some sort in all as in its own body." $\underline{58}$ The progressive, advanced human soul is one that identifies itself with others, which is capable of understanding through its own experience that of others and thus sees its interests and those of others as the same.

Tourreil, among the four writers discussed here, presented the most extreme rejection of a world driven by competition and division among people, and the most fervent embrace of a world in which human beings would be bound to one another by ties of 
love and affection. For Tourreil achieving utopia implied more than just a changed behavioral pattern between individuals: in order to effect genuine societal change, humanity must change its fundamental nature. Change meant, in the religion

fusioniénne, the eradication of individual consciousness and the development of a group identity that would eliminate the possibility of the egotistical impulse in the first place.

\section{[End Page 456]}

\section{Conclusions}

Romantic socialism was in many ways an odd precursor to the socialism we are more familiar with today. Contrary to so-called scientific socialism, it was deeply spiritual, rooted in a wish to remake society along Christian but not Catholic lines. At times surprisingly feminist in its views on women's place in French society, the movement was also important as the training ground for many of the feminist leaders of the Second Republic. $\underline{59}$ Perhaps most surprisingly to those unfamiliar with the movement, many of its thinkers were notably indifferent to economic and political issues, focusing rather on a vision of a radically remade humanity as the path to utopia. This impulse to reform humanity took many shapes; the most ethereal and imaginative among them, however, was in the use of the androgyne as a metaphor for their social agenda.

Leroux, Ganneau, Constant, and Tourreil used the androgyne to symbolize a remade humanity, thereby participating in the larger socialist project of their day. Although they did not all use the image of the androgyne, romantic socialists in general were addressing the same core of issues that the androgyne was invoked to symbolize. Fourierists, in their elaboration of the phalanstery, meditated on the proper balance between the needs of the individual and those of society. In her vision of a worker's union, feminist socialist Flora Tristan focused on the juncture between community and ownership of property. Jeanne Deroin and the other feminists of the period made active use of the androgyne to symbolize their vision of complementarity in sexual relations. The androgyne used by Leroux, Ganneau, Constant, and Tourreil was in many ways a flight of fancy appropriate to the quixotic nature of romantic socialism, but it also reflected the depth of social division felt by nineteenth-century French thinkers. Whether divided between the classes, the sexes, or between the Catholic and the anticlerical, France was seen by romantic socialists to be a fragmented and troubled society. Their socialism, whether embodied by the androgyne or by another form of utopia, was ultimately aimed at reconciling that fragmentation.

\section{Notes}

1. See A. L. J. Busst, "The Image of the Androgyne in the Nineteenth Century," in Romantic Mythologies, ed. Ian Fletcher (New York, 1967). 
2. Carol Pateman, The Sexual Contract (Stanford, Calif., 1988) has been extremely influential here. See Joan Scott, Only Paradoxes to Offer (Cambridge, 1996), introduction, for a thorough discussion of the liberal individual as it pertains to French feminism.

3. Genevi ve Fraisse, Reason's Muse (Chicago, 1994); Joan Landes, Women and the Limits of Citizenship in the Age of the French Revolution (Ithaca, N.Y., 1988); see Carla Hesse, The Other Enlightenment (Princeton, N.J., 2001), for another view on the legacy of the Enlightenment for women.

4. See Lieselotte Steinbrügge, The Moral Sex, trans. Pamela E. Selwyn (New York, 1995); Londa Schiebinger, Nature's Body (Boston, 1993); Joan Landes, Visualizing the Nation (Ithaca, N.Y., 2001).

$\underline{5}$. This is true not only in regard to ideas about women and gender. One of the major themes of romantic socialism was the revival of religious sensibility, if not the Catholic Church, in explicit rejection of Enlightenment materialism. The apolitical cast of many romantic socialists was also linked to their rejection of the eighteenth century; fearing political violence they turned away from that realm altogether.

6. See Dorinda Outram, The Body and the French Revolution (New Haven, Conn., 1989).

7. See Denise Riley, Am I That Name? (Minneapolis, Minn., 1988); and Jacques Donzelot, L'invention du social (Paris, 1984).

8. Claire Goldberg Moses, French Feminism in the Nineteenth Century (Albany, N.Y., 1984).

9. Claudia Moscovici, Gender and Citizenship (New York, 2000). On androgyny, see also Kari Weil, Androgyny and the Denial of Difference (Charlottesville, Va., 1992); and Frédéric Monneyron, L'androgyne romantique: Du mythe au mythe littéraires (Paris, 1994).

10. Among others, see Mircea Eliade, Mephistopheles et l'androgyne (Paris, 1962); J. Evola, La métaphysique du sexe (Paris, 1976); Jean Libis, Le mythe de l'androgyne (Paris, 1980); and Jean Molino, "Le mythe de l'androgyne," in Aimer en France, vol. 2, ed. Paul Viallaneix and Jean Erhard (Clermont-Ferrand, 1980).

11. The marriage motif is also present in the works of Jeanne Deroin and Jean Reynaud. See Scott, Only Paradoxes to Offer; and Jean Reynaud, Terre et ciel (Paris, 1844), 36473. On the Saint-Simonian androgynous god, see Sebastian Charléty, Histoire du SaintSimonisme (1825-1864), 2d ed. (Paris, 1931); Susan Grogan, French Socialism and Sexual Difference (New York, 1992); and Weil, Androgyny.

12. See Maurice Agulhon, Marianne into Battle: Republican Imagery and Symbolism in France, 1789-1880, trans. Janet Lloyd (London, 1979); Grogan, French Socialism; and Stéphane Michaud, Muse et Madone (Paris, 1985).

13. Robert Nye, Masculinity and Male Codes of Honor in Modern France (Berkeley, Calif., 1993); William Reddy, The Invisible Code (Berkeley, Calif., 1997).

14. Victoria Thompson, "Creating Boundaries: Homosexuality and the Changing Social Order in France, 1830-1870," in Homosexuality in Modern France, ed. Jeffrey Merrick 
and Bryant T. Ragan, Jr. (New York, 1996), 105.

15. Pierre Leroux, "De l'individualisme et du socialisme," Oeuvres (1825-1850) (Geneva, 1978).

16. See Jean-Jacques Goblot, Pierre Leroux et ses premiers écrits (Lyon, 1988); Armelle Le Bras-Chopard, De l'égalité dans la différence, le socialisme de Pierre Leroux (Paris, 1986); Jerome Peignot, Pierre Leroux, inventeur du socialisme (Paris, 1988); and P.-Felix Thomas, Pierre Leroux: Sa vie, son oeuvre, sa doctrine (Paris, 1904).

17. Leroux, De l'humanité (Boussac, 1848), 513-50.

18. Leroux, "De l'individualisme et du socialisme."

19. Leroux, De I'humanité, 521, 522.

20. Carol A. Newsom and Sharon H. Ringe, The Women's Bible Commentary (Louisville, Ky., 1992).

21. Leroux, De l'humanité, 525.

22. Ibid., 532.

23. Ibid., 534 .

24. Ibid., 545 .

25. Ibid., 121.

26. Mapah is a combination of mater and pater. See Paul Bénichou, Le temps des proph tes (Paris, 1977), 429-35; Alexandre Erdan, La France mystique: Tableau des excentricités religieuses de ce temps, $2 \mathrm{~d}$ ed. (Amsterdam, 1858), 183-88; Charles Yriarte, Paris grotesque: Les célébrités de la rue (Paris, 1864), 85-125; and Charles Caillaux, Arche de la Nouvelle-Alliance: Prologue par un apôtre évadien (Paris, 1840).

27. See Bénichou, Le temps, 435; and Paul Chacornac, Eliphas Lévi, renovateur de l'occultisme en France (Paris, 1926).

28. Bénichou, Le temps, 430.

29. La montagne de la fraternité, 7 May 1848,2 . The list of contributors was perhaps fabricated, given Victor Considérant's angry request that his name be removed from the masthead printed in this issue.

30. Bénichou, Le temps, 432-33.

31. Ibid., 431. On association, see William H. Sewell, Work and Revolution in France: The Language of Labor from the Old Regime to 1848 (Cambridge, 1980).

32. This notion is most clearly articulated in Religion Saint-Simonienne: Lettre du $P$ re Enfantin á Charles Duveyrier (Paris, 1831). It is often attributed to Saint-Simon himself in a deathbed statement to Olinde Rodrigues.

33. Ganneau, Bapt me, mariage (Paris, 1838), 3. 
34. Ganneau, Bapt me, 3.

35. Ganneau, Waterloo (Paris, 1840), 3, 4.

36. See Susan Grogan, Flora Tristan: Life Stories (New York, 1998), Bénichou, Le temps, 429-35.

37. See, among many others, Grogan, French Socialism; and Moses, French Feminism.

38. Bénichou, Le temps, 430.

39. Constant later became known as Eliphas Lévi, the historian of magic. See Chacornac, Eliphas Lévi; and Frank Paul Bowman, ed., Eliphas Lévi, visionnaire romantique (Paris, 1969).

40. Constant, La $m$ re de Dieu (Paris, 1841), 79.

41. Ibid.

42. Ibid., 122.

43. Ibid., 297.

44. Ibid., 299.

45. Ibid., 299, 272.

46. Ibid., 301.

47. Ibid., 302.

48. On Tourreil, see Erdan, La France mystique, 188-206; Frank Paul Bowman, Le Christ romantique (Geneva, 1973); idem, "Religion, Politics, and Utopia in French Romanticism," Australian Journal of French Studies 11 (1974): 307-24; and Auguste Viatte, Victor Hugo et les illuminés de son temps (Montreal, 1942).

49. Erdan, La France mystique, 189.

50. Erdan never mentions the word androgyny, despite its overwhelming centrality to the doctrine. As Erdan makes clear in his subtitle, the climate in the mid-1850s had very little tolerance for the eccentricities of the previous two decades. Tourreil's one known disciple, Auguste Guyard, wrote several proposed constitutions, the first in the 1840 s and the last in the 1880s; in the later works all mention of androgyny has disappeared. See these two examples, nearly identical despite somewhat different titles: Des droits des devoirs et des constitutions au point de vue de la doctrine fusioniénne, 1848, Paris, Biblioth que Nationale de France (BN) LB54-1243; Des droits, des devoirs et des constitutions au point de vue de la destinée humaine: A Barmouth, au si ge de la société pour la propagation du fusionisme, 3d ed., 1882, BN 8-R-4239.

51. Jean Maitron, Dictionnaire biographique du mouvement ouvrier fran ais (Paris, 1964), 465.

52. Ibid. Tourreil, with Léopold Amail, a former Saint-Simonian, helped to found the 
Compagnie des Industries Unies in Paris in 1845. For biography on Tourreil, see Maitron, Dictionnaire biographique.

53. Louis-Jean Baptiste de Tourreil, La religion fusioniénne (Tours, 1879), 124.

54. Ibid.

55. Ibid.

56. Ibid., 653 .

57. Ibid., 146.

58. Ibid., 162-63.

59. See, among others, Mich le Riot-Sarcey, La démocratie á l'épreuve des femmes, 1830-1848 (Paris, 1994); Laure Adler, A l'aube du féminisme: Les premi res journalistes, 1830-1850 (Paris, 1973); and Marguerite Thibert, Le féminisme dans le socialisme fran ais de 1830 á 1848 (Paris, 1926). 